\title{
Ensiled pulp from biorefining increased milk production in dairy cows compared with grass-clover silage
}

\author{
Vinni Kragbæk Damborg, ${ }^{1}$ Søren Krogh Jensen, ${ }^{1}$ Marianne Johansen, ${ }^{1}$ Morten Ambye-Jensen, ${ }^{2}$ \\ and Martin Riis Weisbjerg ${ }^{1 *}$ \\ ${ }^{1}$ Department of Animal Science, Aarhus University, Blichers Allé 20, 8830, Tjele, Denmark \\ ${ }^{2}$ Department of Engineering, Aarhus University, Hangøvej 2, 8200 Aarhus N, Denmark
}

\section{ABSTRACT}

The objective of the current study was to examine the effect of fibrous pulp and partial substitution of soybean meal with green protein concentrate from biorefining of grass-clover on dry matter intake, milk production, digestibility, and eating behavior in dairy cows compared with untreated grass-clover silage and soybean meal. Biorefining of grass-clover occurred right after harvest in a production-scale twin-screw press. The twin-screw pressing separated the grass-clover into a pulp and a green juice. The green juice was fermented using lactic acid bacteria for protein precipitation and then decanted, and the precipitate was heat dried to constitute the green protein concentrate. From the same field, grass-clover was harvested $6 \mathrm{~d}$ later due to rainy weather and was prewilted before ensiling. The pulp and the grass-clover were ensiled in bales without additives. The production trial consisted of an incomplete $6 \times 4$ Latin square trial ( 3 -wk periods; 12 wk total) including 36 lactating Holstein cows. The trial had 6 treatments in a $2 \times 3$ factorial design with 2 forage types (grass-clover silage and pulp silage) and 3 protein treatments (low protein, high protein with soybean meal, and high protein with a mixture of soybean meal and green protein). The trial was designed to test silage type, protein type, protein level, and the interaction between protein level and silage type. The forage:concentrate ratio was 55:45 in low protein total mixed rations (TMR) and 51:49 in high protein TMR. Low protein and high protein TMR were composed of 372 and $342 \mathrm{~g} / \mathrm{kg}$ of $\mathrm{DM}$ of experimental silages, respectively, and green protein supplemented TMR was composed of $28.5 \mathrm{~g} / \mathrm{kg}$ of DM of green protein. Silage type did not affect dry matter intake of cows. The average energy-corrected milk yield was 37.0 and 33.4 $\mathrm{kg} / \mathrm{d}$ for cows fed pulp silage and grass-clover silage,

Received December 4, 2018.

Accepted June 9, 2019.

*Corresponding author: martin.weisbjerg@anis.au.dk respectively, resulting in an improved feed efficiency in the cows receiving pulp silage. Milk fat concentration was greater in milk from cows fed pulp silage, and milk protein concentration was lower compared with milk from cows fed grass-clover silage. The in vivo digestibility of crude protein and neutral detergent fiber was greater for pulp silage diets compared with grass-clover silage diets. Eating rate was greater, whereas daily eating duration was lower, for pulp silage diets compared with grass-clover silage diets. The partial substitution of soybean meal with green protein did not affect dry matter intake, milk yield, or eating behavior. The in vivo digestibility of crude protein in green protein supplemented diets was lower compared with soybean meal diets. The results imply that extraction of protein from grassland plants can increase the value of the fiber part of grassland plants.

Key words: green protein, ruminant, digestibility, eating behavior

\section{INTRODUCTION}

The globally increasing demand for animal protein increases the requirement for feed protein, and at the same time, interest in sustainable and locally grown sources of feed protein is increasing (Chadd et al., 2002; Chiesa and Gnansounou, 2011).

Grassland plants have great potential of becoming such a source, through biorefining (Pirie, 1978; Damborg et al., 2018). These plants have several advantages for the environment and climate already in the field in the form of carbon sequestration, decreased nitrogen leaching, high yields of DM and protein, and so on (Jensen et al., 2012; Manevski et al., 2018). Furthermore, the AA composition of grassland plants is comparable to soybean meal, and through biorefining, a protein concentrate for monogastrics can be produced alongside a potentially improved forage for ruminants (Damborg et al., 2018; Stødkilde et al., 2018). Biorefining of grassland plants entails an enhanced sustainable utilization of the nutrients in the biomass (e.g., through 
fractionation into products with different characteristics and purposes; Morais and Bogel-Lukasik, 2013). Grassland plants are an important source of minerals, vitamins, and fatty acids (FA) for dairy cows; however, detailed knowledge regarding the distribution of nutrients in the fractions through the biorefining process is limited.

Upon maceration in a twin-screw press, grassland plants are separated into a liquid protein-rich juice and a fibrous pulp. From the juice, a protein-rich concentrate is precipitated and dried (Santamaría-Fernández et al., 2018). The resulting protein concentrate is well suited as a protein supplement, and ensiled pulp is suited as forage for ruminants (Bruins and Sanders, 2012; Stødkilde et al., 2019).

The pulp obtained after screw pressing will have an increased concentration of insoluble nutrients such as fibers, but the digestibility of the pulp fibers may be improved, as a result of the disruption of fibers and breakage of cell walls (Hong et al., 1988; Damborg et al., 2018). This physical treatment may affect eating and drinking behavior of cows. Furthermore, juice extraction produces a pulp with a greater DM concentration, thus no prewiliting is necessary before ensiling (Kung, 2010).

The objectives of the present study were (a) to compare pulp silage to grass-clover silage, (b) to examine whether silage type interacts with diet protein level, and (c) to assess the value of green protein as a partial substitute for soybean meal, when fed to lactating dairy cows with respect to DMI, milk production, milk composition, digestibility, and eating behavior.

The hypotheses of the study were that removal of easily degradable nutrients and increasing the concentration of fiber in the pulp would decrease the digestibility of pulp silage diets compared with grass-clover silage diets, resulting in lower DMI and ECM production on pulp silage diets compared with grass-clover silage diets. Furthermore, it was hypothesized that green protein could be used as a substitute for a proportion of soybean meal in dairy cow diets without impairing DMI and ECM production.

\section{MATERIALS AND METHODS}

\section{Experimental Feeds}

The production of protein concentrate and pulp silage from grass-clover was a massive collaboration involving partners from academia and industry (see Acknowledgments and the demo-scale production study by Santamaría-Fernández et al., 2018).

The grass-clover was produced by an organic farmer in southwestern Denmark $\left(55^{\circ} 69^{\prime} \mathrm{N}, 8^{\circ} 37^{\prime} \mathrm{E}\right)$. The grass- clover was sown and established in spring 2013 with pea as cover crop, and in 2016 first regrowth was used. The botanical composition was perennial ryegrass (Lolium perenne L.), hybrid ryegrass (Lolium hybridum L.), red clover (Trifolium pratense L.), and white clover (Trifolium repens L.), and the grass:clover ratio was 45:55.

A total of $444 \mathrm{t}$ of fresh grass-clover was harvested and processed from June 29 to July 1, 2016. In the field, grass-clover was mowed in swaths, directly picked by a loader wagon, and immediately transported 6 $\mathrm{km}$ to Nybro Tørreri A.m.b.a. (Varde, Denmark) and weighed. Here, it was cut to a theoretical length of 40 to $50 \mathrm{~mm}$. The grass-clover had a DM concentration of $190 \mathrm{~g} / \mathrm{kg}$ and a CP concentration of $172 \mathrm{~g} / \mathrm{kg}$ (for more details, see the study by Santamaría-Fernández et al., 2018). The cut grass-clover was loaded into the existing input system of Nybro Tørreri and conveyed into a Vincent twin-screw press (TSP-12; Vincent Corporation, Tampa, Florida). The extracted green juice was heated to $39^{\circ} \mathrm{C}$ and acidified to $\mathrm{pH} 3.5$ to 4.5 by lactic acid fermentation with an inoculated bacteria culture. The fermented green juice ( $16.8 \%$ of the input DM) was transported to KMC (Kartoffelmelcentralen A.m.b.a., Karup, Denmark), where the protein concentrate and a residual brown juice were separated in a decanter centrifuge before the protein concentrate was dried in a spin flash drier. Further details on the processing can be found in the study by Santamaría-Fernández et al. (2018).

The pulp ( $79.0 \%$ of the input DM, the remaining $4.2 \%$ of DM was lost as foam and so on) was baled and wrapped by a CLAAS Uniwrap 455 (CLAAS, Harsewinkel, Germany) with 12 layers of plastic for ensiling without additives. The control grass-clover silage was produced from the same field; grass-clover was mowed (July 6, 2016) and prewilted for $1 \mathrm{~d}$ before it was chopped and ensiled in round bales without additives.

\section{Cows, Experimental Design, Feed Composition, and Sampling}

The experiment was carried out at the research barn at Aarhus University (Foulum, Denmark) and complied with guidelines set by the Danish Ministry of Environment and Food (Law No. 474, May 15, 2014; Danish Ministry of Environment and Food, 2014) regarding animal experimentation and care for animals used for scientific purposes.

Thirty-six lactating Danish Holstein cows were used, including 12 first-lactation and 24 older cows. At the beginning of the experiment, milk yield averaged $( \pm \mathrm{SD})$ $35 \pm 8.3 \mathrm{~kg}$ of ECM/d, cows were $72 \pm 46$ DIM (range: 17 to $174 \mathrm{DIM}$ ), and weighed $545 \pm 50 \mathrm{~kg}$ (first lactation) and $642 \pm 59 \mathrm{~kg}$ (older cows). Cows were kept in 
a loose-housing system with cubicles in 3 sections of 12 cows (2 blocks). One section was used for first-lactation cows, and 2 sections were used for older cows.

Cows were blocked in blocks of 6 according to parity (first lactation and older) and DIM and were randomly assigned to 1 of 6 experimental diets in one of six $6 \times$ 4 incomplete Latin square designs with 6 cows, 6 diets, and 4 experimental periods of $21 \mathrm{~d}$ and with a $2 \times 3$ factorial arrangement of treatments including 2 silage types and 3 protein treatments. The Latin square design was selected to extract cow-to-cow variation from residual variation, and different Latin squares were used for each block to balance out potential residual effects of earlier treatments.

Three diets were based on grass-clover silage: low $\mathrm{CP}$ concentration $(\mathbf{G})$, high $\mathrm{CP}$ concentration with soybean meal (GS), and high CP concentration with green protein and soybean meal $(\mathbf{G G p S})$, and 3 were based on pulp silage: low $\mathrm{CP}$ concentration $(\mathbf{P})$, high $\mathrm{CP}$ concentration with soybean meal (PS), and high $\mathrm{CP}$ concentration with green protein and soybean meal (PGpS). Ingredient compositions and measured chemical compositions of the TMR are shown in Table 1.

The proportion of green protein concentrate was lower than the desired full substitution because a limited total amount was available. Titanium dioxide was included as an external marker in the TMR (Table 1).

Rations were formulated to meet requirements of the Nordic feed evaluation system (Norfor, Volden, 2011), except low-protein diets, which were designed to be deficient in RDP.
The TMR were mixed in a Cormall auger mixer (Cormall A/S, Sønderborg, Denmark) for $15 \mathrm{~min}$. Silage bales were used for a maximum of $2 \mathrm{~d}$ after opening, and the remainder of the bale was discarded. Samples were taken from every grass-clover and pulp bale by drill $14 \mathrm{~d}$ before feeding to measure DM for ration formulation. Samples were taken of every silage bale when opened, and samples of concentrate ingredients were taken every week of the trial for DM determination and for pooled samples each covering 6 -wk periods for chemical analysis of each feedstuff. Additionally, a sample of each TMR was taken from the morning feeding on d 18 to 21 in each period, and DM concentration was determined at $60^{\circ} \mathrm{C}$ for $48 \mathrm{~h}$ and used to calculate daily DMI. A pooled sample within period for each TMR was used for chemical analysis.

Cows were fed twice daily for ad libitum intake with a target residue of 3 to $5 \mathrm{~kg}$. Feed intake and number and duration of visits were recorded automatically using the Insentec RIC system (Insentec, Marknesse, the Netherlands), where each cow was assigned an individual feeding trough throughout the study. Cows had free access to drinking water (2 Insentec water troughs per 12 cows).

The feed intake was measured continuously for each individual cow, and troughs were emptied before each morning feeding. At d 19 to 22 of each period, DM was determined on feed residues.

Manure subsamples from each cow were collected at $1400 \mathrm{~h}$ on d 19 to 21 and at $0800 \mathrm{~h}$ on d 20 to 22 in each period and frozen. After each period, fecal samples were

Table 1. Ration ingredients and measured chemical composition $(\mathrm{g} / \mathrm{kg}$ of DM unless otherwise specified) of diets

\begin{tabular}{|c|c|c|c|c|c|c|}
\hline \multirow[b]{2}{*}{ Item } & \multicolumn{6}{|c|}{$\operatorname{Diet}^{1}$} \\
\hline & $\mathrm{G}$ & GS & GGpS & $\mathrm{P}$ & PS & PGpS \\
\hline Grass-clover silage & 372 & 342 & 342 & 0 & 0 & 0 \\
\hline Pulp silage & 0 & 0 & 0 & 372 & 342 & 342 \\
\hline Maize silage & 177 & 163 & 163 & 177 & 163 & 163 \\
\hline Green protein & 0 & 0 & 28.5 & 0 & 0 & 28.5 \\
\hline $\mathrm{NaOH}$ wheat & 133 & 122 & 122 & 133 & 122 & 122 \\
\hline Rapeseed cake & 111 & 102 & 102 & 111 & 102 & 102 \\
\hline Dried sugar beet pulp & 62.0 & 69.2 & 59.0 & 62.0 & 69.2 & 59.0 \\
\hline Vitamin and mineral mix & 12.4 & 11.3 & 11.3 & 12.4 & 11.3 & 11.3 \\
\hline Titanium dioxide & 0.967 & 0.890 & 0.890 & 0.967 & 0.890 & 0.890 \\
\hline \multicolumn{7}{|l|}{ Chemical composition $^{2}$} \\
\hline $\mathrm{DM}, \mathrm{g} / \mathrm{kg}$ fresh & $585 \pm 13$ & $598 \pm 14$ & $597 \pm 9.6$ & $423 \pm 14$ & $439 \pm 18$ & $443 \pm 15$ \\
\hline
\end{tabular}

${ }^{1}$ Diets: grass-clover silage and low protein $(\mathrm{G})$; grass-clover silage and soybean meal (GS); grass-clover silage, green protein, and soybean meal (GGpS); pulp silage and low protein (P); pulp and soybean meal (PS); pulp, green protein, and soybean meal (PGpS).

${ }^{2}$ Measured values, means $\pm \mathrm{SD}$ of samples pooled from periods 1 and 2 and from periods 3 and $4, \mathrm{n}=2$. 
thawed, pooled for each cow and period, and scored on a scale of 1 to 5 ( 1 was loose and 5 was firm) with 0.5 steps. Afterward, the fecal samples were dried at $60^{\circ} \mathrm{C}$ for $48 \mathrm{~h}$ before milling and chemical analysis.

Cows were milked twice daily (0515 and $1645 \mathrm{~h}$ ). The milk yield was measured using a SAC-IDC (S. A. Christensen \& Co., Kolding, Denmark) milk measurer at milking. Samples for fat, protein, and lactose analyses were taken from the afternoon milking on d 19 to 21 and the morning milking on d 20 to 22 in each period.

\section{Chemical Analyses}

Samples of individual feedstuffs, TMR, and feces were dried at $60^{\circ} \mathrm{C}$ for $48 \mathrm{~h}$ for DM determination. Samples for analysis were ground to $1 \mathrm{~mm}$. Crude ash was determined in all samples after incinerated at $525^{\circ} \mathrm{C}$ for 6 h (AOAC International, 2000). Nitrogen concentration in feedstuffs, TMR, and feces was measured by the Dumas method (Hansen, 1989), using a Vario MAX CN (Elementar Analysesysteme GmbH, Hanau, Germany), and was multiplied by 6.25 to convert into CP. Soluble $\mathrm{N}$ in silages was determined by a 1-h extraction in a borate-phosphate buffer at $39^{\circ} \mathrm{C}$ and $\mathrm{pH} 6.75$ (Åkerlind et al., 2011). The concentration of ammonia $\mathrm{N}$ in silages was determined using a kit based on glutamate dehydrogenase (AM 1015; Randox Laboratories Ltd., Crumlin, UK) and a Cobas Mira auto-analyzer (Triolab A/S, Brondby, Denmark).

Neutral detergent fiber was determined in silages, concentrate feedstuffs, TMR, and feces using $\alpha$-amylase and sodium sulfite according to Mertens (2002) on a Fibertech M6 system (Foss Analytical, Hillerød, Denmark) and corrected for residual ash. Starch concentration in maize silage and concentrate feedstuffs was determined by an enzymatic colorimetric method (Bach Knudsen et al., 1987). Total sugars in silages were analyzed by the Luff-Schoorl method (European Commission, 2012), method 71/250/EEC.

The concentration of lactic, acetic, succinic, propionic, and butyric acid in silages was analyzed according to Jensen et al. (1995) and Canibe et al. (2007) using a Hewlett Packard gas chromatograph (model 6890, Agilent Technologies Inc., Wilmington, DE) having a flame ionization detector and a 30-m SGE BP1 column (Scientific Instrument Services, Ringoes, NJ).

Silages were acidified in nitric acid and destructed at $1,500 \mathrm{~W}$ at $230^{\circ} \mathrm{C}$ for $25 \mathrm{~min}$ in a microwave digestion system (Ultra Wave, single reaction chamber, Milestone, Shelton, CT) for determination of mineral (Na, Mg, P, K, Ca, Mn, Fe, Cu, Zn) concentrations. The concentration was determined using inductively coupled plasma mass spectrometry (ICP-MS) on an X
seriesII ICP-MS with a conventional Mainhard nebulizer and a Peltier cooled quartz impact bead spray chamber at $3{ }^{\circ} \mathrm{C}$ (Thermo Electron Coorperation, Bremen, Germany).

Titanium dioxide was measured in TMR and feces after digestion with sulfuric acid, and absorbance was measured after addition of hydrogen peroxide (Myers et al., 2004).

Milk samples were analyzed for protein, fat, and lactose concentrations on a Milkoscan 400 infrared analyzer at Eurofins Steins Laboratorium (Vejen, Denmark) and weighted with morning and evening milk yield to obtain average daily concentrations of protein, fat, and lactose monohydrate.

Lipids in feedstuffs was analyzed following an acid Bligh and Dyer extraction (Jensen, 2008). Samples were acidified in $80^{\circ} \mathrm{C}(3 \mathrm{~mol} / \mathrm{L}) \mathrm{HCl}$ for $1 \mathrm{~h}$ and extracted in a mixture of chloroform and methanol (Bligh and Dyer, 1959).

Lipids for FA determination in milk were extracted according to the method of Bligh and Dyer (1959). Fatty acid extracts were quantified as FA methyl esters, as described by Jensen and Nielsen (1996), using a gas chromatograph (Hewlett Packard 6890 series; Agilent Technologies, Palo Alto, CA) equipped with an automatic on-column injector (Hewlett Packard 7673; split ratio of 4.325:1), a capillary column of $30 \mathrm{~m} \times$ $320 \mu \mathrm{m}$ i.d., $0.25-\mu \mathrm{m}$ film thickness (Omegawax; Supelco 4-293-415; Sigma-Aldrich, St. Louis, MO), and a flame-ionization detector. The internal standard used was C17:0.

Fat-soluble vitamins in feedstuffs and milk were extracted and analyzed by HPLC as described by Jensen and Nielsen (1996) and Jensen et al. (1998). A PerkinElmer HS-5-Silica column $(4.0 \times 125 \mathrm{~mm}$; Waltham, MA) was used for analyses of $\alpha$-tocopherol and retinol, and lutein was separated on a $4.6 \times 250 \mathrm{~mm}$ Supelcosil LC-NHr5 $\mu$ ๆ HPLC column (Supelco Inc., Bellefonte, PA).

\section{In Vitro and In Situ Analyses}

In vitro digestibility of $\mathrm{OM}$ in silages was measured by anaerobic fermentation in diluted rumen fluid for 48 $\mathrm{h}$, followed by incubation of undissolved material in a pepsin- $\mathrm{HCl}$ solution for $48 \mathrm{~h}$ (Tilley and Terry, 1963). For concentrate feedstuffs enzymatic OM digestibility was determined according to Weisbjerg and Hvelplund (1993).

For in situ studies, feed samples were milled on a cutter mill with a $1.5-\mathrm{mm}$ screen. For indigestible NDF determination, silage samples were incubated in the rumen for $288 \mathrm{~h}$ in Dacron bags with a pore size of 
$12 \mu \mathrm{m}$ in 3 nonlactating cows fed at maintenance, and indigestible NDF concentration was determined as the residual NDF (Åkerlind et al., 2011). For determination of NDF and CP disappearance characteristics, samples of silages, green protein, and soybean meal were filled into Dacron bags with a pore size of $38 \mu \mathrm{m}$ and incubated in the abovementioned cows for $0,2,4,8,16,24$, 48, and $96 \mathrm{~h}$ and additionally $168 \mathrm{~h}$ for NDF disappearance. For determination of total-tract digestibility of $\mathrm{CP}$ in silages, green protein, and soybean meal, the mobile bag technique as described by Hvelplund et al. (1992) was used. Experimental silages, green protein, and soybean meal in Dacron bags with pore size $12 \mu \mathrm{m}$ were preincubated in the rumen of the aforementioned cows for $16 \mathrm{~h}$. Subsequently, the bags were immersed in $\mathrm{HCl}(\mathrm{pH} 2.4)$ for $1 \mathrm{~h}$ and then in pepsin- $\mathrm{HCl}$ for $2 \mathrm{~h}$ at $39^{\circ} \mathrm{C}$ rotating in a Daisy incubator (ANKOM Technology Corporation, Fairport, NY). The bags were then inserted into the duodenum of 3 duodenum cannulated lactating cows and collected from the feces. For protein determination, rumen and mobile bags were washed, and residues were transferred to $\mathrm{N}$-free filter paper for $\mathrm{N}$-determination using the Kjeldahl procedure (AOAC International, 2005). For NDF determination, bag residues were transferred to filter crucibles and neutral detergent boiled as described above.

\section{Calculations}

The estimated in vivo OM digestibility (OMD) was calculated as $4.10+0.959 \times$ in vitro $\mathrm{OM}$ digestibility for grass-clover and pulp silages, as $6.73+0.950 \times$ in vitro OM digestibility for maize silages, and as $5.38+$ $0.867 \times$ in vitro enzymatic OM digestibility for concentrate (Åkerlind et al., 2011).

Disappearance characteristics were calculated according to the equation by McDonald (1981) accounting for lag time: $\operatorname{Dis}(t)=a+b \times\left[1-e^{-c(t-l)}\right]$, where Dis $(t)$ represents the disappearance at time $t(\mathrm{~g} / \mathrm{kg}), a$ represents the immediately soluble fraction $(\mathrm{g} / \mathrm{kg}), b$ represents the insoluble but rumen-degradable fraction $(\mathrm{g} / \mathrm{kg}), c$ represents the fractional rate of disappearance of fraction $b(/ \mathrm{h})$, and $l$ represents the lag time $(\mathrm{h})$. The NDF disappearance values were corrected for potential initial particle loss by relating the NDF residues to the 0-h NDF residue, which was only washed.

Energy-corrected milk $(3.14 \mathrm{MJ} / \mathrm{kg})$ was calculated according to Sjaunja et al. (1991) using the equation ECM yield $(\mathrm{kg})=$ milk yield $(\mathrm{kg}) \times[38.3 \times$ fat $(\mathrm{g} /$ $\mathrm{kg})+24.2 \times$ protein $(\mathrm{g} / \mathrm{kg})+15.71 \times$ lactose $(\mathrm{g} / \mathrm{kg})$ $+20.7] / 3,140$, where lactose was measured as lactose monohydrate. For result calculations, the milk yield was averaged over the last $3 \mathrm{~d}$ of each period. The DMI was averaged over the last $4 \mathrm{~d}$ of each period.

Titanium oxide concentrations in TMR and feces were used to calculate apparent digestibility of nutrients in the TMR.

The duration and number of meals was defined such that a new meal was initiated if more than $8 \mathrm{~min}$ had passed since the termination of the previous visit in the feeding box (Dürst et al., 1993). Drinking periods were defined such that a new period was initiated if more than $4 \mathrm{~min}$ had passed since termination of the previous visit in the drinking trough (Dado and Allen, 1994).

\section{Statistical Analysis}

Data were analyzed using the MIXED procedure of SAS software (version 9.4, 2016; SAS Institute Inc., Cary, NC). Model parameters included period (1-4), parity (primiparous, multiparous), and treatment (G, GS, GGpS, P, PS, and PGpS) as fixed effects; cow as random effect; and parity $\times$ period and parity $\times$ treatment interactions. Contrasts were used to determine whether effects existed for silage type, protein level, protein source, and an interaction between the level of protein and the silage type. Some variables on eating and drinking behavior were $\log _{10}$ or inverse transformed to obtain a homogeneity of variance and normality of residuals. These variables are presented transformed with statistics in the table along with the back-transformed data. Two cows in period 4 were discarded from the analysis because of influenza, not related to the feed treatments, and the last day of the trial was discarded from the analysis because of a gate failure that allowed cows to eat from the outside of the troughs. Reported values are least squares means, and statistical significance was considered at $P$-values $\leq 0.05$, whereas tendencies were regarded at $0.05<P<0.10$.

\section{RESULTS}

\section{Chemical Composition of Feeds}

Chemical compositions of feedstuffs in the diets are shown in Table 2. The DM concentration was $313 \mathrm{~g} /$ $\mathrm{kg}$ for pulp silage and $514 \mathrm{~g} / \mathrm{kg}$ for grass-clover silage. The concentration of CP was $179 \mathrm{~g} / \mathrm{kg}$ of DM in pulp silage and $161 \mathrm{~g} / \mathrm{kg}$ of DM in grass-clover silage. In pulp silage, the OMD (71.6\%) was somewhat lower than in grass-clover silage $(73.2 \%)$. Green protein had a protein concentration of $332 \mathrm{~g} / \mathrm{kg}$ of DM.

The concentrations of lactic acid, acetic acid, and propionic acid were greater in pulp silage than in grass- 


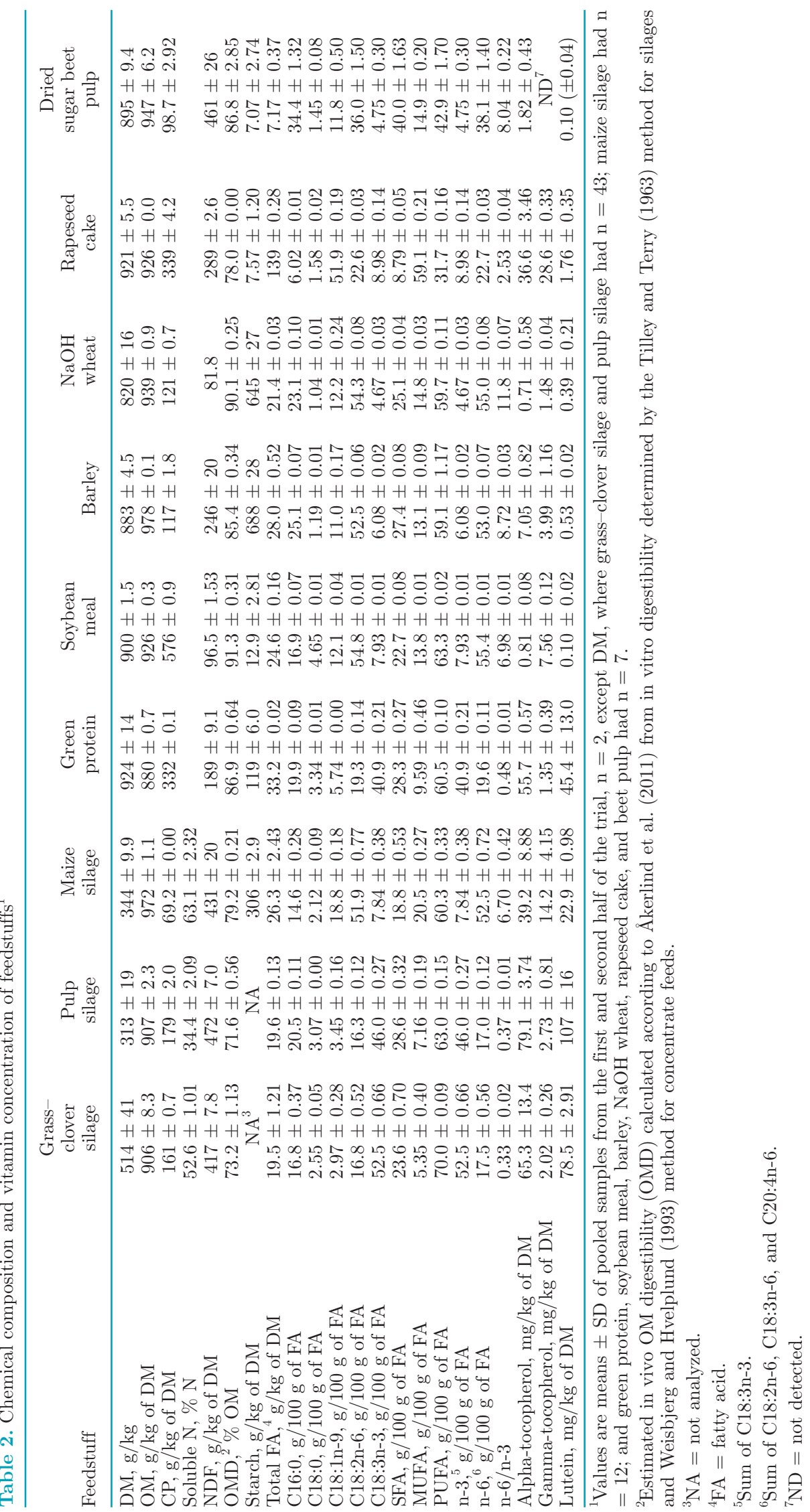


Table 3. Fermentation characteristics and mineral concentration of experimental silages and maize silage ${ }^{1}$

\begin{tabular}{lccc}
\hline Feedstuff & $\begin{array}{c}\text { Grass-clover } \\
\text { silage }\end{array}$ & $\begin{array}{c}\text { Pulp } \\
\text { silage }\end{array}$ & $\begin{array}{c}\text { Maize } \\
\text { silage }\end{array}$ \\
\hline Ammonia N, \% N & $3.28 \pm 0.02$ & $3.66 \pm 0.34$ & $7.09 \pm 0.66$ \\
Total sugars, g/kg of DM & $169 \pm 3.62$ & $\mathrm{ND}$ & $\mathrm{NA}$ \\
$\mathrm{pH}$ & $4.55 \pm 0.07$ & $3.80 \pm 0.00$ & $3.65 \pm 0.07$ \\
Lactic acid, g/kg of DM & $20.9 \pm 18.2$ & $53.5 \pm 0.64$ & $32.7 \pm 8.54$ \\
Acetic acid, g/kg of DM & $2.85 \pm 0.40$ & $19.7 \pm 0.17$ & $11.4 \pm 0.81$ \\
Succinic acid, g/kg of DM & $0.55 \pm 0.30$ & $1.34 \pm 0.19$ & $3.21 \pm 0.10$ \\
Propionic acid, g/kg of DM & $\mathrm{ND}$ & $0.15 \pm 0.02$ & $\mathrm{ND}$ \\
Butyric acid, g/kg of DM & 0.09 & $\mathrm{ND}$ & $\mathrm{ND}$ \\
$\mathrm{Na}, \mathrm{g} / \mathrm{kg}$ of DM & $3.47 \pm 0.16$ & $2.97 \pm 0.20$ & $0.39 \pm 0.04$ \\
$\mathrm{Mg}, \mathrm{g} / \mathrm{kg}$ of DM & $2.87 \pm 0.11$ & $2.76 \pm 0.01$ & $1.26 \pm 0.05$ \\
$\mathrm{P}, \mathrm{g} / \mathrm{kg}$ of DM & $3.36 \pm 0.09$ & $12.9 \pm 0.03$ & $2.01 \pm 0.12$ \\
$\mathrm{~K}, \mathrm{~g} / \mathrm{kg}$ of DM & $16.9 \pm 0.75$ & $9.87 \pm 0.35$ & $9.26 \pm 0.49$ \\
$\mathrm{Ca}, \mathrm{g} / \mathrm{kg}$ of DM & $9.51 \pm 0.22$ & $85.1 \pm 0.59$ & $2.31 \pm 0.09$ \\
$\mathrm{Mn}, \mathrm{mg} / \mathrm{kg}$ of DM & $83.0 \pm 11.2$ & $594 \pm 16$ & $71.4 \pm 8.78$ \\
$\mathrm{Fe}, \mathrm{mg} / \mathrm{kg}$ of DM & $449 \pm 76$ & $10.2 \pm 0.27$ & $3.44 \pm 0.29$ \\
$\mathrm{Cu}, \mathrm{mg} / \mathrm{kg}$ of DM & $8.63 \pm 0.12$ & $56.4 \pm 0.75$ & $15.3 \pm 3.38$ \\
$\mathrm{Zn}, \mathrm{mg} / \mathrm{kg}$ of DM & $49.2 \pm 0.3$ & &
\end{tabular}

${ }^{1}$ Values are means \pm SD of pooled samples from the first and second half of the trial, $\mathrm{n}=2$, except DM, where grass-clover silage and pulp silage had $\mathrm{n}=43$; maize silage had $\mathrm{n}=12$; and green protein, soybean meal, barley, $\mathrm{NaOH}$ wheat, rapeseed cake, and beet pulp had $\mathrm{n}=7$. ND $=$ not detected; $\mathrm{NA}=$ not analyzed.

clover silage, resulting in a lower $\mathrm{pH}$ in pulp silage (Table 3). The proportion of ammonia $\mathrm{N}$ in total $\mathrm{N}$ and the concentration of butyric acid was low for both experimental silages.

The concentration of macrominerals, except calcium, was lower in pulp silage than in grass-clover silage, whereas for all examined microminerals, the concentration was greater in pulp silage than in grass clover silage (Table 3 ).

Alpha-tocopherol, gamma-tocopherol, and lutein concentrations were greater in pulp silage than in grass-clover silage. Compared with the other concentrate feedstuffs, the concentration of $\alpha$-tocopherol and lutein were high in green protein, whereas the concentration of gamma-tocopherol was low in green protein.

Table 4 shows the CP disappearance characteristics of grass-clover silage, pulp silage, green protein, and soybean meal, and it shows the NDF disappearance characteristics of grass-clover and pulp silages. The disappearance rate of $\mathrm{CP}$ was $12.9 \% / \mathrm{h}$ in grass-clover silage and $12.1 \% / \mathrm{h}$ in pulp silage, $6.58 \% / \mathrm{h}$ for green protein, and $12.5 \% / \mathrm{h}$ for soybean meal.

Disappearance rate of NDF was $0.051 / \mathrm{h}$ for grassclover silage and $0.059 / \mathrm{h}$ for pulp silage. The lag time was lower for grass-clover silage $(1.47 \mathrm{~h})$ compared with pulp silage $(2.29 \mathrm{~h})$, even though the indigestible

Table 4. Disappearance parameters, lag time, and total-tract digestibility of $\mathrm{CP}$ ( $\mathrm{g} / \mathrm{kg}$ of $\mathrm{CP}$ unless otherwise specified) in experimental feeds and soybean meal and disappearance parameters and lag time of NDF ( $\mathrm{g} / \mathrm{kg}$ of NDF unless otherwise specified) and indigestible NDF (iNDF) in experimental silages ${ }^{1}$

\begin{tabular}{|c|c|c|c|c|c|c|}
\hline \multirow[b]{2}{*}{ Item $^{2}$} & \multicolumn{4}{|c|}{$\mathrm{CP}$ disappearance } & \multicolumn{2}{|c|}{ NDF disappearance } \\
\hline & $\begin{array}{l}\text { Grass-clover } \\
\text { silage }\end{array}$ & $\begin{array}{l}\text { Pulp } \\
\text { silage }\end{array}$ & $\begin{array}{c}\text { Green } \\
\text { protein }^{3}\end{array}$ & $\begin{array}{c}\text { Soybean } \\
\text { meal }\end{array}$ & $\begin{array}{l}\text { Grass-clover } \\
\text { silage }\end{array}$ & $\begin{array}{l}\text { Pulp } \\
\text { silage }\end{array}$ \\
\hline$a$ & $681 \pm 3.6$ & $591 \pm 8.0$ & $368 \pm 7.4$ & $170 \pm 0.04$ & & \\
\hline$b$ & $255 \pm 8.9$ & $339 \pm 5.8$ & $617 \pm 11$ & $830 \pm 0.04$ & $794 \pm 0.8$ & $787 \pm 0.2$ \\
\hline$a+b$ & $936 \pm 5.3$ & $930 \pm 2.2$ & $986 \pm 3.7$ & $1,000 \pm 0.00$ & & \\
\hline$c, \% / \mathrm{h}$ & $12.9 \pm 0.10$ & $12.1 \pm 1.56$ & $6.58 \pm 0.05$ & $12.5 \pm 0.05$ & $5.09 \pm 0.001$ & $5.93 \pm 0.04$ \\
\hline iNDF, $g / \mathrm{kg}$ of $\mathrm{NDF}$ & & & & & $208 \pm 12.1$ & $212 \pm 10.3$ \\
\hline
\end{tabular}

${ }^{1}$ Values are means \pm SE of pooled samples from the first and second half of the trial, $\mathrm{n}=2$.

${ }^{2} a=$ the immediately soluble fraction; $b=$ the insoluble but rumen-degradable fraction; $a+b=$ the potential degradable fraction; $c=$ rate of disappearance of fraction $b$.

${ }^{3}$ Spin-flash-dried green protein.

${ }^{4}$ Measured using the mobile bag technique (Hvelplund et al., 1992). 
Table 5. Dry matter intake and intake of total CP, OM, and NDF (kg/d unless otherwise specified)

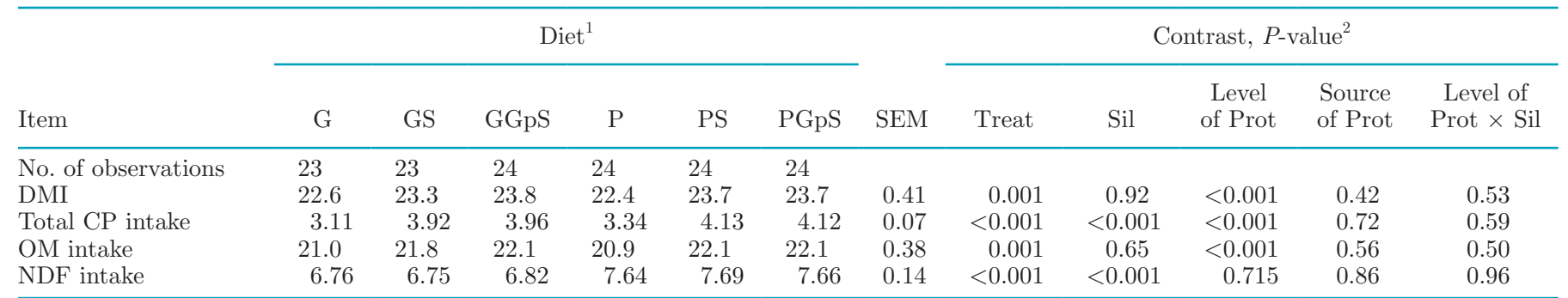

${ }^{1}$ Diets: grass-clover silage and low protein $(\mathrm{G})$; grass-clover silage and soybean meal (GS); grass-clover silage, green protein, and soybean meal (GGpS); pulp silage and low protein (P); pulp and soybean meal (PS); pulp, green protein, and soybean meal (PGpS).

${ }^{2}$ Treat $=$ treatment, Sil $=$ experimental silage, Prot $=$ protein. Probability of contrasts; Sil = G, GS, and GGpS versus P, PS, and PGpS; Level of Prot $=$ G and P versus GS, GGpS, PS, and PGpS; Source of Prot $=$ GS and PS versus GGpS and PGpS; Level of Prot $\times$ Sil $=$ G, PS, and PGpS versus $\mathrm{P}, \mathrm{GS}$, and GGpS.

NDF concentration in NDF was similar (208 and 212 $\mathrm{g} / \mathrm{kg}$ of NDF, respectively).

\section{Feed Intake}

Dry matter intake (Table 5) was not different for cows receiving grass-clover diets $(23.2 \mathrm{~kg} / \mathrm{d})$ compared with cows receiving pulp diets $(23.3 \mathrm{~kg} / \mathrm{d})$ but was lower for low protein diets compared with high protein diets. Furthermore, protein level and silage type did not interact. The total CP intake was greater for pulp diets $(3.86 \mathrm{~kg} / \mathrm{d})$ than for the grass-clover diets $(3.66 \mathrm{~kg} / \mathrm{d})$. The protein source did not affect DMI.

With the FA proportions seen in Table 2, the average daily supply of total n-6 FA from grass-clover silage diets and pulp silage diets was similar (276 and $275 \mathrm{~g} / \mathrm{d}$ ), whereas the daily dietary supply of n-3 FA was $165 \mathrm{~g} / \mathrm{d}$ from pulp silage diets and $182 \mathrm{~g} / \mathrm{d}$ from grass-clover silage diets. The supply of n-3 FA was 179 $\mathrm{g} / \mathrm{d}$ from green protein supplemented diets and $167 \mathrm{~g} / \mathrm{d}$ from soybean meal diets.

\section{Milk}

Table 6 shows daily milk production and chemical composition of milk. Daily ECM was greater for cows receiving pulp diets $(37.0 \mathrm{~kg} / \mathrm{d})$ compared with cows receiving grass-clover diets $(33.4 \mathrm{~kg} / \mathrm{d})$. In addition, feed efficiency ( $\mathrm{kg}$ of $\mathrm{ECM} / \mathrm{kg}$ of DMI) was greater for cows receiving pulp diets compared with cows receiving grass-clover diets. No interaction existed between protein level and silage type on the ECM yield, and no effect of protein source existed.

Milk fat concentration was greater, whereas milk protein concentration was lower, when cows were fed high protein pulp diets compared with high protein grass-clover diets. The daily production of milk fat and milk protein was greater from cows receiving pulp diets than from cows receiving grass-clover diets. Protein sources did not affect milk production or fat, protein, and lactose concentration.

The concentration of n-3 FA was lower in milk from cows fed grass-clover diets $(0.75 \mathrm{~g} / 100 \mathrm{~g}$ of FA), whereas the concentration of n- 6 FA was greater $(3.21 \mathrm{~g} / 100$ $\mathrm{g}$ of FA), compared with milk from cows fed pulp diets (0.86 and $3.01 \mathrm{~g} / 100 \mathrm{~g}$ of $\mathrm{FA}$, respectively), resulting in a greater $n-6 / n-3$ ratio in milk from cows fed grassclover diets. Furthermore, the concentration of PUFA tended to be lower in milk from cows fed pulp diets compared with milk from cows fed grass-clover diets $(P=0.096)$; there was a relatively larger decrease in C18:2n-6 concentration compared with the increase in C18:3n-3 concentration. Partial substitution of soybean meal with green protein resulted in a greater concentration of C18:3n-3 in milk (0.87 g/100 g of FA) compared with diets with soybean meal $(0.74 \mathrm{~g} / 100 \mathrm{~g}$ of FA).

Cows fed grass-clover diets produced milk with a greater concentration of $\alpha$-tocopherol compared with cows fed pulp diets, whereas the concentration of retinol was not affected by silage type $(P=0.14)$. A tendency was seen toward a lower concentration of $\alpha$-tocopherol and retinol in milk from cows supplemented with green protein compared with cows receiving soybean meal $(P$ $=0.075$ and $P=0.056$, respectively).

\section{In Vivo Digestibility and Feces}

The fecal DM concentration was greater for green protein supplemented diets than for soybean meal diets (Table 7). The in vivo digestibility of $\mathrm{DM}, \mathrm{OM}, \mathrm{CP}$, and NDF for pulp diets was greater compared with that of grass-clover diets. Furthermore, for high protein diets, the in vivo digestibility of $\mathrm{DM}, \mathrm{OM}, \mathrm{CP}$, and NDF was greater compared with low protein diets, and the increase was larger in grass-clover silage diets compared with pulp silage diets. 
Table 6. Milk yield and composition

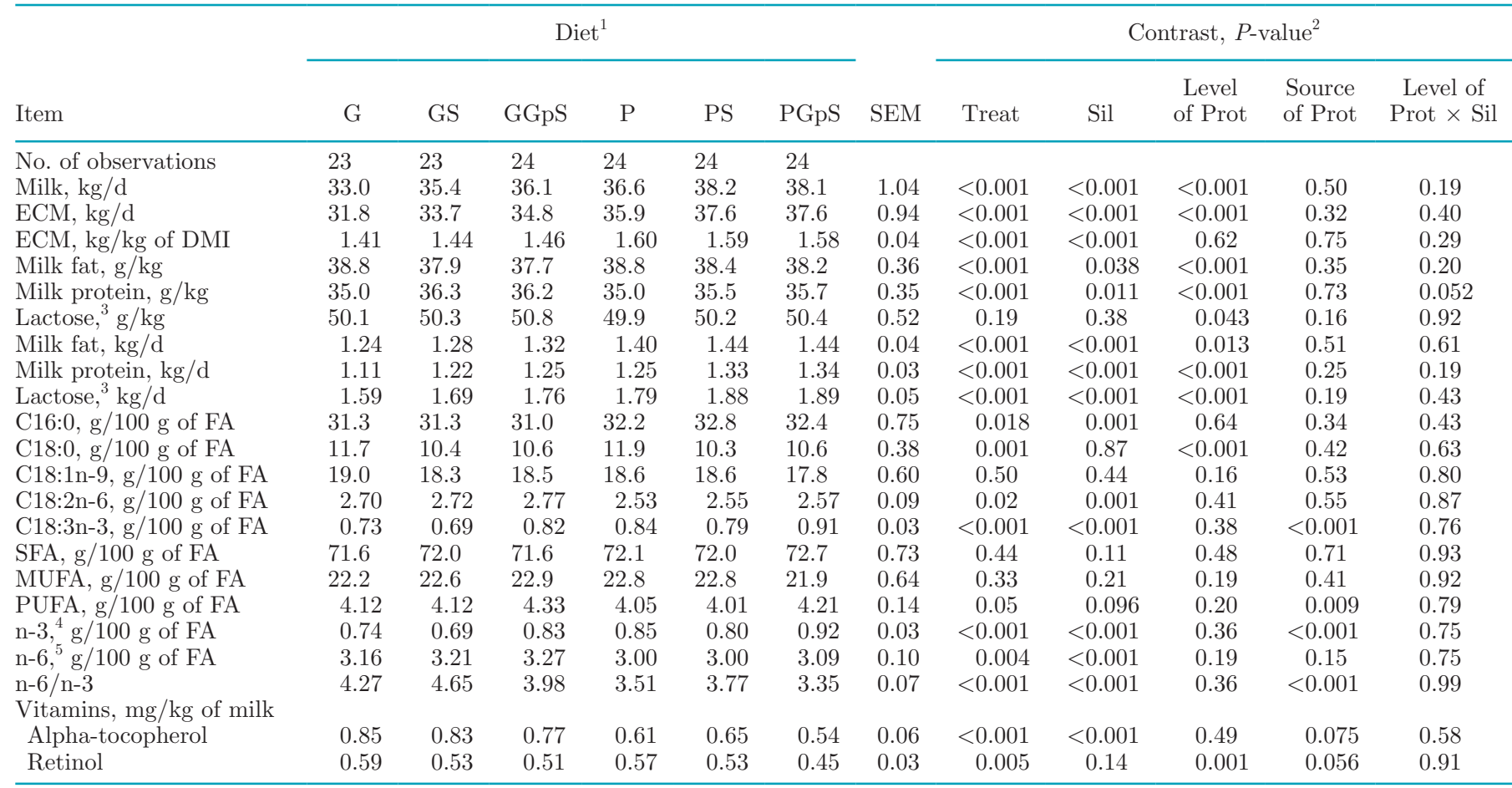

${ }^{1}$ Diets: grass-clover silage and low protein $(\mathrm{G})$; grass-clover silage and soybean meal (GS); grass-clover silage, green protein, and soybean meal (GGpS); pulp silage and low protein (P); pulp and soybean meal (PS); pulp, green protein, and soybean meal (PGpS).

${ }^{2}$ Treat $=$ treatment, Sil = experimental silage, Prot = protein. Probability of contrasts; Sil = G, GS, and GGpS versus P, PS, and PGpS; Level of Prot $=$ G and P versus GS, GGpS, PS, and PGpS; Source of Prot $=$ GS and PS versus GGpS and PGpS; Level of Prot $\times$ Sil $=$ G, PS, and PGpS versus $\mathrm{P}$, GS, and GGpS.

${ }^{3}$ Lactose is expressed as lactose monohydrate.

${ }^{4}$ Sum of C18:3n-3 and C20:5n-3.

${ }^{5}$ Sum of C18:2n-6, C18:3n-6, and C20:4n-6.

\section{Water Intake and Drinking and Eating Behavior}

Daily intake of free water (drinking) was greater for cows receiving grass-clover silage diets than for cows receiving pulp silage diets and greater for cows receiving high protein diets than for cows receiving low protein diets (Table 8 ). The daily intake of feed water was greater for cows receiving pulp silage diets compared

Table 7. Fecal output, score, and composition and digestibility of nutrients in dairy cows

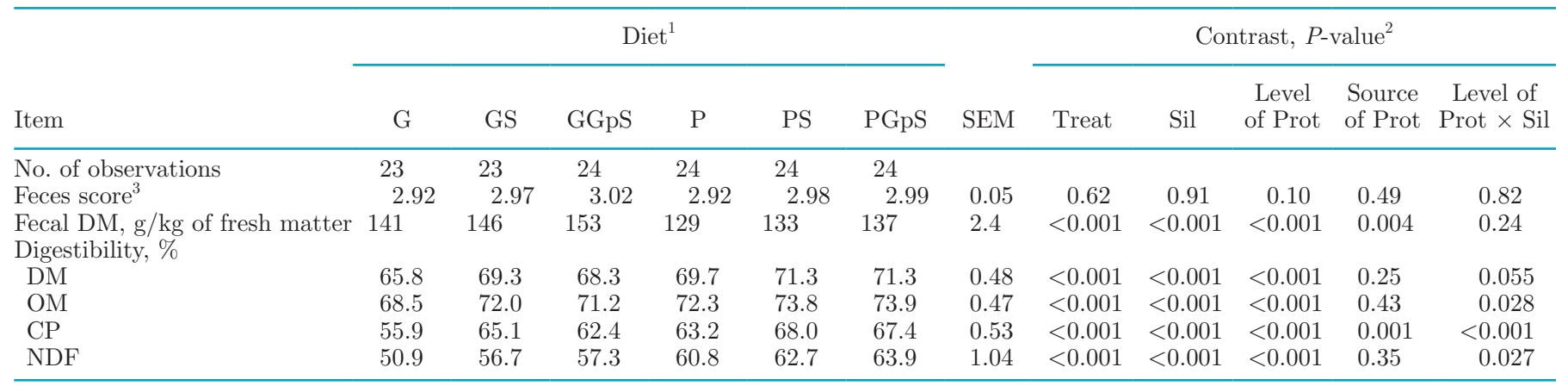

${ }^{1}$ Diets: grass-clover silage and low protein $(\mathrm{G})$; grass-clover silage and soybean meal (GS); grass-clover silage, green protein, and soybean meal (GGpS); pulp silage and low protein (P); pulp and soybean meal (PS); pulp, green protein, and soybean meal (PGpS).

${ }^{2}$ Treat $=$ treatment, $\mathrm{Sil}=$ experimental silage, Prot $=$ protein. Probability of contrasts; Sil = G, GS, and GGpS versus P, PS, and PGpS; Level of Prot $=$ G and P versus GS, GGpS, PS, and PGpS; Source of Prot $=$ GS and PS versus GGpS and PGpS; Level of Prot $\times$ Sil $=$ G, PS, and PGpS versus $\mathrm{P}$, GS, and GGpS.

${ }^{3}$ Scored on a scale of 1 to 5 ( 1 was loose and 5 was firm) with 0.5 -increment steps. 
with cows receiving grass-clover silage diets. The total daily water intake (sum of free water and feed water) was greater for cows receiving the grass-clover silage diets $(90.1 \mathrm{~kg} / \mathrm{d})$ compared with cows receiving pulp silage diets $(88.2 \mathrm{~kg} / \mathrm{d})$ and greater for cows receiving high protein diets than for cows receiving low protein diets.

Cows receiving grass-clover diets spend less time daily drinking and had a greater drinking rate compared with cows receiving pulp silage diets. Protein source did not affect drinking behavior.

The cows receiving grass-clover diets spent more time daily eating compared with cows fed pulp diets. The cows fed grass-clover silage had fewer meals compared with the cows fed pulp silage; thus, the eating rate was lower for grass-clover silage diets than for pulp silage diets. The protein source did not affect the eating behavior.

\section{DISCUSSION}

\section{Experimental Silages and Green Protein}

The high DM concentration in grass-clover silage was due to sunny and windy weather at harvest and prewilting compared with rain during processing and baling of the pulp. The lower CP concentration in grass-clover silage compared with pulp silage is probably mainly due to the 6-d delay in harvest of the grass-clover (Solati et al., 2018), because CP concentration in pulp after extraction of green juice generally is similar to the original grass or legumes (Damborg et al., 2018). The high NDF concentration and lower in vitro OMD in pulp silage compared with grass-clover silage was as expected, due to removal of solubles during processing (Damborg et al., 2018). Earlier studies have shown lower ash concentration in pulp than in original grass or legume (Damborg et al., 2018); however, in the present study, ash concentrations in pulp silage and grass-clover silage were similar. This could potentially be caused by more soil contamination in the grass-clover for pulp production due to rainy weather during harvest and processing, which was also shown in the high ash concentration of the green protein.

Pulp and grass-clover were well ensiled without additives. The $\mathrm{pH}$ in pulp silage was considerably lower than in grass-clover silage, probably due to the lower DM concentration (Kung, 2010). Even though, some sugar was removed from the pulp during the physical processing, the fermentation did not appear to have been restricted. Lactic acid composed $853 \mathrm{~g} / \mathrm{kg}$ of the fermentation products in grass-clover silage and 716 $\mathrm{g} / \mathrm{kg}$ of the fermentation products in pulp silage. The lower concentrations of lactic and acetic acids in the grass-clover silage indicate a restrictive fermentation due to the greater DM concentration (Kung, 2010). The lower concentration of soluble $\mathrm{N}$ in pulp silage compared with grass-clover silage was probably due to the extraction of soluble $\mathrm{N}$ with the green juice.

Table 8. Water intake and drinking and eating behavior

\begin{tabular}{|c|c|c|c|c|c|c|c|c|c|c|c|c|}
\hline \multirow[b]{2}{*}{ Item } & \multicolumn{6}{|c|}{$\operatorname{Diet}^{1}$} & \multirow[b]{2}{*}{ SEM } & \multicolumn{5}{|c|}{ Contrast, $P$-value ${ }^{2}$} \\
\hline & G & GS & GGpS & $\mathrm{P}$ & PS & PGpS & & Treat & Sil & $\begin{array}{l}\text { Level } \\
\text { of Prot }\end{array}$ & $\begin{array}{l}\text { Source } \\
\text { of Prot }\end{array}$ & $\begin{array}{c}\text { Level of } \\
\text { Prot } \times \text { Sil }\end{array}$ \\
\hline Free water, L/d & 77.1 & 83.5 & 81.6 & 71.4 & 77.3 & 76.3 & 1.83 & $<0.001$ & $<0.001$ & $<0.001$ & 0.21 & 0.98 \\
\hline Feed water, L/d & 9.31 & 9.40 & 9.63 & 13.0 & 13.3 & 13.2 & 0.22 & $<0.001$ & $<0.001$ & 0.084 & 0.75 & 0.81 \\
\hline Duration, $\log _{10}(\min / d)$ & 1.04 & 1.11 & 1.11 & 1.12 & 1.16 & 1.15 & 0.03 & $<0.001$ & $<0.001$ & $<0.001$ & 0.67 & 0.20 \\
\hline Duration, ${ }^{3} \mathrm{~min} / \mathrm{d}$ & 11.0 & 13.0 & 12.8 & 13.1 & 14.3 & 14.1 & & & & & & \\
\hline Drinking periods per day & 0.15 & 0.14 & 0.15 & 0.15 & 0.13 & 0.13 & 0.01 & 0.008 & 0.010 & 0.008 & 0.39 & 0.66 \\
\hline Drinking periods per day ${ }^{3}$ & 6.53 & 7.17 & 6.72 & 6.85 & 7.45 & 7.54 & & & & & & \\
\hline \multicolumn{13}{|l|}{ Eating behavior } \\
\hline Duration, $\min / \mathrm{d}$ & 282 & 277 & 271 & 221 & 223 & 231 & 9.56 & $<0.001$ & $<0.001$ & 0.86 & 0.84 & 0.16 \\
\hline Meals, $\log _{10}$ (no.) & 0.94 & 0.97 & 0.96 & 1.03 & 1.04 & 1.05 & 0.01 & $<0.001$ & $<0.001$ & 0.025 & 0.59 & 0.51 \\
\hline
\end{tabular}

${ }^{1}$ Diets: grass-clover silage and low protein $(\mathrm{G})$; grass-clover silage and soybean meal (GS); grass-clover silage, green protein, and soybean meal (GGpS); pulp silage and low protein (P); pulp and soybean meal (PS); pulp, green protein, and soybean meal (PGpS).

${ }^{2}$ Treat $=$ treatment, Sil = experimental silage, Prot = protein. Probability of contrasts; Sil = G, GS, and GGpS versus P, PS, and PGpS; Level of Prot $=$ G and P versus GS, GGpS, PS, and PGpS; Source of Prot $=$ GS and PS versus GGpS and PGpS; Level of Prot $\times$ Sil $=$ G, PS, and PGpS versus P, GS, and GGpS.

${ }^{3}$ Back-transformed means from the transformed data above. 
The lower concentration of monovalent minerals (Na, $\mathrm{Mg}, \mathrm{P}$, and $\mathrm{K}$ ) and greater concentration of commonly protein-bound divalent microminerals $(\mathrm{Ca}, \mathrm{Mn}, \mathrm{Fe}, \mathrm{Cu}$, and $\mathrm{Zn}$ ) in the pulp silage might be related to monovalent minerals being dissolved in the juice and, therefore, decreased in concentration in the pulp silage, and protein-bound microminerals remaining in the pulp.

\section{Disappearance}

The disappearance kinetics of $\mathrm{CP}$ confirm that the concentration of easily accessible protein was lower in pulp silage compared with grass-clover silage; the immediately soluble fraction, $a$, was greater in grassclover silage compared with pulp silage, whereas the insoluble but rumen-degradable fraction, $b$, was lower.

The different ensiling characteristics of the silages may also influence disappearance characteristics. The high DM concentration of grass-clover, resulting in a restrictive fermentation, would reduce protein degradation during ensiling. The lower DM in pulp compared with grass-clover probably caused a more extensive fermentation. Martineau et al. (2006) showed that extensive fermentation could induce a greater lag time, which may partially cause the greater lag time of pulp silage seen in the present study.

Interestingly, the NDF disappearance parameters $b$ and $c$ were similar between grass-clover silage and pulp silage even though grass-clover silage had a greater in vitro OMD than the pulp silage. Thus, the processing, delayed harvest of grass-clover silage, and the differences in fermentation characteristics appear to counteract.

The differences between green protein and soybean meal in the $a$ and $b$ fractions were balanced as the potential degradable fraction $a+b$ was similar. Chowdhury et al. (2018) also showed an increasing $a$ fraction and decreasing $b$ fraction in heat-dried green protein.

\section{Feed Intake}

The DMI of pulp silage diets was expected to be lower than that of grass-clover silage diets based on the lower in vitro OMD and the greater NDF concentration, even though the particle size was reduced by processing. Interestingly, these effects either cancelled out each other or had little effect, because the DMI was similar on the 2 types of silage. In the present study DMI was based on DM determination at $60^{\circ} \mathrm{C}$, and because the concentration of fermentation products was greater in pulp silage compared with grass-clover silage, the drying losses of fermentation products might also be greater. According to Åkerlind et al. (2011), the corrected DM concentration would be $332 \mathrm{~g} / \mathrm{kg}$ for pulp silage and $517 \mathrm{~g} / \mathrm{kg}$ for grass-clover silage. These estimates are based on drying pure silages; however, if similar losses are assumed upon drying TMR, the DM corrections would have increased DMI for pulp silage diets approximately $0.5 \mathrm{~kg}$ compared with grass-clover silage.

As the $\mathrm{CP}$ and $\mathrm{NDF}$ concentrations were greater in the pulp and thereby in pulp silage diets, total intake of $\mathrm{CP}$ and NDF was greater for cows fed pulp silage. The OM intake did not differ between silage types, and neither did the ash concentration. The inclusion level of green protein used in the present study did not affect DMI. From the present study, it is difficult to conclude whether a greater inclusion would affect DMI.

\section{Milk Yield and Composition}

The increase in ECM and milk yield from cows fed pulp silage compared with cows fed grass-clover silage was not expected because DMI was similar on the 2 silage types and in vitro OMD was lower for pulp silage. Mertens and Koegel (1996) showed similar results of increased milk yield at similar DMI of macerated hay and silage versus untreated; however, they did not remove a large proportion of solubles before feeding such as in the present study. Although, in a study by Koegel et al. (1992), mechanical processing did not result in increased milk yield.

The greater feed efficiency or feed conversion $(\mathrm{kg}$ of $\mathrm{ECM} / \mathrm{kg}$ of DMI) of pulp was also reflected in studies by Pijlman et al. (2018) and Hellwing et al. (2018). Hellwing et al. (2018) used the same silages as for the present study and showed a greater methane emission from heifers eating pulp silage compared with heifers eating grass-clover silage, suggesting that more fiber was degraded and used. However, the results by Hellwing et al. (2018) may be confounded by the same delayed harvest of grass-clover as in the present study. Other studies have not shown increased feed efficiency. A report by Klop et al. (2015) showed similar feed efficiency of pulp silage and grass-clover silage, and in a study by Savonen et al. (2018), green juice was extracted from grass silages and the feed efficiency of diets with 25 or $50 \%$ silage-pulp was lower compared with diets with untreated grass silage. The possible underestimation of DMI for pulp diets due to drying losses of fermentation products may have led to an overestimation of the feed efficiency in cows receiving pulp silage diets. However, even if the DMI was corrected for loss of fermentation products, the feed efficiency in cows fed pulp silage diets would still be greater compared with cows fed grass-clover diets.

In the current study, the grass-clover for silage was harvested 6 d later than the grass-clover for pulp 
production. Johansen et al. (2017) reported a drop in ECM yield of $1.0 \mathrm{~kg} / \mathrm{d}$ when harvest of perennial ryegrass was postponed 13 d, and Randby et al. (2012) reported a drop in ECM yield of $2.0 \mathrm{~kg} / \mathrm{d}$ when harvest of a grass-red clover sward was postponed $7 \mathrm{~d}$. In both abovementioned studies, the change in milk yield corresponded to changes in DMI; therefore, the feed efficiency was independent of harvest time. The greater milk yield and feed efficiency ( $\mathrm{kg}$ of ECM/ $\mathrm{kg}$ of DMI) observed in the current study is therefore most likely not caused by the difference in harvest time for the 2 silages.

Increasing dietary protein caused a decreased milk fat concentration, in accordance with earlier reported values (Alstrup et al., 2014), and it caused an increased milk protein concentration, as expected. However, in milk from cows receiving pulp silage diets, the increase in protein concentration was not as high as the increase in milk from cows receiving grass-clover silage diets, maybe because the $\mathrm{CP}$ concentration in the pulp silage diets was slightly greater (protein level $\times$ silage interaction $P=0.052$ ). Ideally, the $\mathrm{CP}$ concentration in grass-clover diets and pulp diets should have been similar, because $\mathrm{CP}$ concentration in pulp after protein extraction was expected to be similar to the original grass-clover (Damborg et al., 2018), although this was not possible due to the delayed harvest of grass-clover. The experimental silages had different CP concentrations, and it was chosen not to change ration composition to make pulp and grass-clover diets isonitrogenous, because such a diet modification would hamper comparison of the experimental silages.

The greater proportion of n-3 FA in milk from cows fed pulp silage was unexpected because the proportion of n-3 FA in the pulp silage was lower than the proportion in grass-clover silage. The present results suggest that there is an increased transfer of n-3 FA from feed to milk, due to a less efficient biohydrogenation of n-3 FA (Petersen and Jensen, 2014), in the rumen of cows receiving pulp diets in spite of greater NDF concentration in the diet and increased in vivo OM digestibility.

The greater n-3 FA and lower n- 6 FA proportion of FA from cows fed pulp silage diets compared with cows fed grass-clover silage diets resulted in a lower n- $6 / \mathrm{n}-3$ ratio, which can be considered beneficial for human health (Simopoulos, 2002).

The concentration of retinol in the milk corresponds well to values at 0.43 to $0.50 \mathrm{mg} / \mathrm{kg}$ found by Adler et al. (2013), though the concentration of $\alpha$-tocopherol found in the present study was somewhat lower than the values 1.28 to $1.46 \mathrm{mg} / \mathrm{kg}$ also reported by Adler et al. (2013), probably due to a greater milk yield and concentrate:forage ratio in the present study.
Because of the greater concentration of $\alpha$-tocopherol in pulp silage and green protein compared with grassclover silage and soybean meal, it was expected that the highest concentration of $\alpha$-tocopherol would be found in milk from cows fed pulp silage and green protein supplemented diets. However, the opposite was found, and at present, an explanation for this is lacking.

\section{Digestibility and Feces}

The feces score was unaffected by experimental silage and protein level or source, even though the DM concentration in the feces was considerably lower for cows fed pulp silage.

The greater in vivo digestibility of $\mathrm{OM}$ in pulp silage diets compared with grass-clover silage diets was due to greater in vivo digestibility of both NDF and CP. The greater in vivo digestibility of NDF and CP in pulp silage diets was potentially caused by the physical processing of the pulp in the twin-screw press, increasing the degradability of the fiber and fiber-bound nutrients, as was found for lucerne hay by Hong et al. (1988). The increase in $\mathrm{CP}$ digestibility could partly be due to a greater concentration of $\mathrm{CP}$ in pulp diets (Weisbjerg et al., 2002). The greater in vivo digestibility of NDF and $\mathrm{CP}$ were unexpected based on the in vitro OMD of the experimental silages, which was lower for pulp silage compared with grass-clover silage. Reversely, the in vivo OM digestibility from the production trial was greater for pulp silage. This suggest that processing effects on digestion might be masked in laboratory methods using dried and ground samples. Furthermore, this indicate that the delayed harvest of grass-clover silage was not the only factor affecting the NDF digestibility. However, other studies have not found an increased digestibility of DM, CP, or NDF resulting from physical treatment (Broderick et al., 1999; Savonen et al., 2018), and further studies are required.

The increased NDF digestibility could, as stated, be due to the 6-d earlier harvest or a result of increased $\mathrm{CP}$ concentration in the pulp diets (Huhtanen et al., 2009). Based on the in situ data, the daily supply of rumen degradable CP to the rumen microbes was similar for grass-clover and pulp silages; thus, the greater NDF digestibility in pulp silage diets might be due to a lower $\mathrm{N}$ requirement when the fiber is physically treated.

\section{Drinking and Eating Behavior}

The daily intake of free water and feed water are naturally dependent on the DM of the diet and the DMI, and the intake of free water also depends on the concentration of dietary protein in the diet, in accor- 
dance with Kume et al. (2010). The greater total intake of water of cows fed grass-clover may be caused by the greater concentration of potassium in the grass-clover silage compared with the pulp silage as also found in other studies (Kume et al., 2010; Fraley et al., 2015).

The cows fed pulp silage spent on average $52 \mathrm{~min} / \mathrm{d}$ less eating compared with the cows fed grass-clover silage, leaving more time for other activities, such as lying; however, the lying time was not recorded in the present study. This extra time could be a contributing factor to the greater milk yield from cows fed pulp silage (Miller-Cushon and DeVries, 2017). One reason for the lower daily eating time could be the smaller particle size of the pulp silage compared with the grass-clover silage, as the pulp silage already had been macerated. A similar trend was shown by Kononoff and Heinrichs (2003), who showed that cows fed short (theoretically $4.8 \mathrm{~mm}$ ) lucerne haylage ate $36 \mathrm{~min} / \mathrm{d}$ less compared with cows fed long (theoretically $22.3 \mathrm{~mm}$ ) lucerne haylage, even though the DMI of short haylage was 3.3 $\mathrm{kg} / \mathrm{d}$ greater than that of long haylage.

Because the DMI was similar for cows fed pulp silage and grass-clover silage, and cows fed pulp silage spent less time eating, the eating rate was greater.

Interestingly, the cows fed pulp silage had a greater number of daily meals than the cows fed grass-clover silage, even though they spent less time eating, and their eating rate was greater than that of the cows fed grass-clover. Similar trends were observed by Johansen et al. (2017) between grass silage and pure white clover silage.

\section{Applications}

The present results indicate that biorefining of grassclover can result in valuable silages for dairy cows. The green protein can be included in ruminant feed or used for monogastric animals, and pulp silage is digestible and valuable as forage for ruminants. However, for the process to be sustainable, the sugar-rich brown juice side stream also has to be used. Although a 6-d difference in harvest existed, we have shown that dairy cows can use the largest fraction from biorefining of grass-clover efficiently, even after a large proportion of soluble nutrients has been removed, thereby adding greatly to the value chain of biorefining.

\section{CONCLUSIONS}

Grass-clover and pulp from biorefining of grass-clover ensiled well without the use of silage additives in spite of different DM concentrations. The DMI was similar for cows receiving pulp silage and grass-clover silage harvested $6 \mathrm{~d}$ later, yet the ECM production was greater for cows receiving pulp silage diets. The in vivo $\mathrm{CP}$ and NDF digestibility in the dairy cows receiving pulp diets was greater compared that in dairy cows receiving grass-clover diets. Furthermore, cows receiving pulp silage diets had a greater eating rate, and thus spent less time eating compared with cows on grass-clover silage diets. The substitution of a proportion of soybean meal with green protein had no effect on DMI or ECM production. Results of the present study indicate that maceration of grass-clover in a twin-screw press increases the value of the pulp as silage for high yielding dairy cows and can result in increased production, though due to the delay in harvest of the grass-clover for silage, more studies are required to validate results.

\section{ACKNOWLEDGMENTS}

This study was supported by the Biovalue strategic platform for innovation and research (Biovalue SPIR), co-funded by The Danish Council for Strategic Research (Copenhagen) and The Danish Council for Technology and Innovation (Copenhagen), and the Biobase Green protein project, funded by Aarhus University (Aarhus, Denmark) and the Ministry of Food, Agriculture, and Fisheries (Copenhagen). V. K. Damborg was partly supported by The Graduate School of Science and Technology at Aarhus University. The authors thank all partners involved in the processing of the grass-clover and the execution of the dairy cow trial. We thank Nybro Tørreri A.M.B.A. (Janderup, Denmark) for providing the processing location and on-site logistics; Sønderhøjgård I/S and Preben Lauridsen (Outrup, Denmark) for providing the organic grass-clover; Runi A/S (Tarm, Denmark) for providing the screw-press; Bounum Maskinstation A/S (Ølgod, Denmark) for wrapping bales; J. Chr. Koldkur Transport A/S (Karup, Denmark) for transportation of the fermented green juice to separation and drying facilities; KMC A.M.B.A. (Karup, Denmark) for decanting the fermented juice and drying the protein concentrate; Biotest Aps, Pauli Kiel, Margrethe Andersen (Middelfart, Denmark) for advice and participation in the processing trial; SEGES, Erik Fog (Aarhus, Denmark), Organofinery, Maria Santamaria-Fernandez, and Mette Lübeck (Copenhagen, Denmark) for construction of the processing trial and active participation during the trial; Simon Finneman Jensen and Simon Søegaard Kristensen (Aarhus University, Foulum, Denmark) for working tirelessly to make the processing trial a success; Jørgen Eriksen (Aarhus University, Foulum, Denmark) for botanical analyses; the barn personnel at Aarhus University, Foulum, for feeding, milking, and animal care; Torkild Nyholm Jacobsen, Amin Aljundi, and 
Mohammed Rashed Chowdhury (Aarhus University, Foulum, Denmark) for valuable assistance throughout the production trial; and laboratory technicians at the Department of Animal Science at Aarhus University for careful execution of chemical analyses.

\section{REFERENCES}

Adler, S. A., A. V. Dahl, S. K. Jensen, E. Thuen, A. M. Gustavsson, and H. Steinshamn. 2013. Fatty acid composition, fat-soluble vitamin concentrations and oxidative stability in bovine milk produced on two pastures with different botanical composition. Livest. Sci. 154:93-102. https://doi.org/10.1016/j.livsci.2013.03.013.

Åkerlind, M., M. R. Weisbjerg, T. Eriksson, R. Tøgersen, P. Udén, B. L. Ólafsson, O. M. Harstad, and H. Volden. 2011. Feed analyses and digestion methods. Pages 41-54 in NorFor-The Nordic Feed Evaluation System. H. Volden, ed. Wageningen Acad. Publ., Wageningen, the Netherlands.

Alstrup, L., M. R. Weisbjerg, L. Hymoller, M. K. Larsen, P. Lund, and M. O. Nielsen. 2014. Milk production response to varying protein supply is independent of forage digestibility in dairy cows. J. Dairy Sci. 97:4412-4422. https://doi.org/10.3168/jds.2013-7585.

AOAC International. 2000. Official Methods of Analysis of AOAC International. 15th ed. AOAC Int., Gaitherburg, MD.

AOAC International. 2005. Official Methods of Analysis of AOAC International. 18th ed. AOAC Int., Gaithersburg, MD.

Bach Knudsen, K. E., P. Åman, and B. O. Eggum. 1987. Nutritive value of Danish-grown barley varieties, I, carbohydrates and other major constituents. J. Cereal Sci. 6:173-186. https://doi.org/10 .1016/S0733-5210(87)80053-X.

Bligh, E. G., and W. J. Dyer. 1959. A rapid method of total lipid extraction and purification. Can. J. Biochem. Physiol. 37:911-917. https://doi.org/10.1139/o59-099.

Broderick, G. A., R. G. Koegel, M. J. Mauries, E. Schneeberger, and T. J. Kraus. 1999. Effect of feeding macerated alfalfa silage on nutrient digestibility and milk yield in lactating dairy cows. J. Dairy Sci. 82:2472-2485. https://doi.org/10.3168/jds.S0022 -0302(99)75499-8.

Bruins, M. E., and J. P. M. Sanders. 2012. Small-scale processing of biomass for biorefinery. Biofuels Bioprod. Biorefin. 6:135-145. https://doi.org/10.1002/bbb.1319.

Canibe, N., O. Hojberg, J. H. Badsberg, and B. B. Jensen. 2007. Effect of feeding fermented liquid feed and fermented grain on gastrointestinal ecology and growth performance in piglets. J. Anim. Sci. 85:2959-2971. https://doi.org/10.2527/jas.2006-744.

Chadd, S. A., W. P. Davies, and J. M. Koivisto. 2002. Practical production of protein for food animals. Pages 77-123 in FAO Anim. Prod. Health Proc., Bangkok. Publishing Management Service, Information Division, FAO, Viale delle Terme di Caracalla, 00100, Rome, Italy.

Chiesa, S., and E. Gnansounou. 2011. Protein extraction from biomass in a bioethanol refinery-possible dietary applications: Use as animal feed and potential extension to human consumption. Bioresour. Technol. 102:427-436. https://doi.org/10.1016/j.biortech 2010.07.125.

Chowdhury, M. R., S. Lashkari, S. K. Jensen, M. Ambye-Jensen, and M. R. Weisbjerg. 2018. Effects of heat treatment of green protein on in situ protein disappearance and in vitro fatty acid biohydrogenation. J. Agric. Food Chem. 66:8169-8178. https://doi.org/10 $.1021 /$ acs.jafc. 8 b02176.

Dado, R. G., and M. S. Allen. 1994. Variation in and relationships among feeding, chewing, and drinking variables for lactating dairy cows. J. Dairy Sci. 77:132-144. https://doi.org/10.3168/jds.S0022 -0302(94)76936-8.

Damborg, V. K., L. Stødkilde, S. K. Jensen, and M. R. Weisbjerg. 2018. Protein value and degradation characteristics of pulp fibre fractions from screw pressed grass, clover, and lucerne. Anim. Feed Sci. Technol. 244:93-103. https://doi.org/10.1016/j.anifeedsci .2018.08.004.
Danish Ministry of Environment and Food. 2014. Bekendtgørelse af lov om dyrefors $\varnothing$ g. LBK 474 . Accessed May 15, 2014. https://www .retsinformation.dk/eli/lta/2014/474. (In Danish)

Dürst, B., M. Senn, and W. Langhans. 1993. Eating patterns of lactating dairy cows of three different breeds fed grass ad lib. Physiol. Behav. 54:625-631. https://doi.org/10.1016/0031-9384(93)90069 $-\mathrm{R}$.

European Commission. 2012. First Commission Directive 71/250/EEC Establishing Community Methods of Analysis for the Official Control of Feeding-Stuffs. The Commission of the European Communities, Brussels, Belgium.

Fraley, S. E., M. B. Hall, and T. D. Nennich. 2015. Effect of variable water intake as mediated by dietary potassium carbonate supplementation on rumen dynamics in lactating dairy cows. J. Dairy Sci. 98:3247-3256. https://doi.org/10.3168/jds.2014-8557.

Hansen, B. 1989. Determination of nitrogen as elementary N, an alternative to Kjeldahl. Acta Agric. Scand. 39:113-118. https://doi .org/10.1080/00015128909438504.

Hellwing, A. L. F., V. K. Damborg, P. Lund, S. K. Jensen, and M. R. Weisbjerg. 2018. Enteric methane emissions from heifers fed grass-clover silage or pulp silage made from grass-clover. Page 455 in Proc. European Fed. Anim. Sci., 69th Annu. Mtg. Wageningen Acad. Publ., Dubrovnik, Croatia.

Hong, B. J., G. A. Broderick, R. G. Koegel, K. J. Shinners, and R. J. Straub. 1988. Effect of shredding alfalfa on cellulolytic activity, digestibility, rate of passage, and milk production. J. Dairy Sci. 71:1546-1555. https://doi.org/10.3168/jds.S0022-0302(88)79718 $-0$.

Huhtanen, P., M. Rinne, and J. Nousiainen. 2009. A meta-analysis of feed digestion in dairy cows. 2. The effects of feeding level and diet composition on digestibility. J. Dairy Sci. 92:5031-5042. https:// doi.org/10.3168/jds.2008-1834.

Hvelplund, T., M. R. Weisbjerg, and L. S. Andersen. 1992. Estimation of the true digestibility of the rumen undegraded dietary protein in the small intestine of ruminants by the mobile bag technique. Acta Agric. Scand. Sect. A-Anim. Sci. 42:34-39. https://doi.org/ 10.1080/09064709209410106.

Jensen, E. S., M. B. Peoples, R. M. Boddey, P. M. Gresshoff, H. Hauggaard-Nielsen, B. J. R. Alves, and M. J. Morrison. 2012. Legumes for mitigation of climate change and the provision of feedstock for biofuels and biorefineries. A review. Agron. Sustain. Dev. 32:329364. https://doi.org/10.1007/s13593-011-0056-7.

Jensen, M. T., R. P. Cox, and B. B. Jensen. 1995. Microbial production of skatole in the hind gut of pigs given different diets and its relation to skatole deposition in backfat. J. Anim. Sci. 61:293-304. https://doi.org/10.1017/S1357729800013837.

Jensen, S. K. 2008. Improved Bligh and Dyer extraction procedure. Lipid Technol. 20:280-281. https://doi.org/10.1002/lite.200800074.

Jensen, S. K., C. Jensen, K. Jakobsen, R. M. Engberg, J. O. Andersen, C. Lauridsen, P. Sorensen, L. H. Skibsted, and G. Bertelsen. 1998. Supplementation of broiler diets with retinol acetate, $\beta$-carotene or canthaxanthin: Effect on vitamin status and oxidative status on broilers in vivo and on meat stability. Acta Agric. Scand. A Anim. Sci. 48:28.

Jensen, S. K., and K. N. Nielsen. 1996. Tocopherols, retinol, betacarotene and fatty acids in fat globule membrane and fat globule core in cows' milk. J. Dairy Res. 63:565-574.

Johansen, M., K. Søegaard, P. Lund, and M. R. Weisbjerg. 2017. Digestibility and clover proportion determine milk production when silages of different grass and clover species are fed to dairy cows. J. Dairy Sci. 100:8861-8880. https://doi.org/10.3168/jds.2017-13401.

Klop, A., D. Durksz, J. Zonderland, and B. Koopmans. 2015. Grasraffinage en gebruik van grasvezel in de rundveevoeding. 790. Wageningen Univ., Wageningen, the Netherlands.

Koegel, R. G., R. J. Straub, K. J. Shinners, G. A. Broderick, and D. R. Mertens. 1992. An overview of physical treatments of lucerne performed at Madison, Wisconsin, for improving properties. J. Agric. Eng. Res. 52:183-191. 10.1016/0021-8634(92)80059-2.

Kononoff, P. J., and A. J. Heinrichs. 2003. The effect of reducing alfalfa haylage particle size on cows in early lactation. J. Dairy Sci. 
86:1445-1457. https://doi.org/10.3168/jds.S0022-0302(03)73728 -X.

Kume, S., K. Nonaka, T. Oshita, and T. Kozakai. 2010. Evaluation of drinking water intake, feed water intake and total water intake in dry and lactating cows fed silages. Livest. Sci. 128:46-51. https:// doi.org/10.1016/j.livsci.2009.10.012.

Kung, L., Jr. 2010. Understanding the biology of silage preservation to maximize quality and protect the environment. Pages $1-14$ in Proc. 2010 California Alfalfa Forage Symp. Corn/Cereal Silage Conf. University of California, Visalia, CA.

Manevski, K., P. E. Lærke, J. E. Olesen, and U. Jørgensen. 2018. Nitrogen balances of innovative cropping systems for feedstock production to future biorefineries. Sci. Total Environ. 633:372-390. 10.1016/j.scitotenv.2018.03.155.

Martineau, R., H. Lapierre, D. R. Ouellet, D. Pellerin, and R. Berthiaume. 2006. In situ degradation of timothy conserved as restrictively or extensively fermented silage or as hay. Can. J. Anim. Sci. 86:299-306. https://doi.org/10.4141/A05-046.

McDonald, I. 1981. A revised model for the estimation of protein degradability in the rumen. J. Agric. Sci. 96:251-252. https://doi .org/10.1017/S0021859600032081.

Mertens, D. R. 2002. Gravimetric determination of amylase-treated neutral detergent fiber in feeds with refluxing in beakers or crucibles: Collaborative study. J. AOAC Int. 85:1217-1240.

Mertens, D. R., and R. G. Koegel. 1996. Maceration of Alfalfa Hay and Silage Improves Milk Production. US Dairy Forage Res. Cent. Madison, WI.

Miller-Cushon, E. K., and T. J. DeVries. 2017. Short communication: Associations between feed push-up frequency, feeding and lying behavior, and milk yield and composition of dairy cows. J. Dairy Sci. 100:2213-2218. 10.3168/jds.2016-12004.

Morais, A. R., and R. Bogel-Lukasik. 2013. Green chemistry and the biorefinery concept. Sustain. Chem. Process. 1:18. https://doi.org/ 10.1186/2043-7129-1-18.

Myers, W. D., P. A. Ludden, V. Nayigihugu, and B. W. Hess. 2004. Technical note: A procedure for the preparation and quantitative analysis of samples for titanium dioxide. J. Anim. Sci. 82:179-183.

Petersen, M. B., and S. K. Jensen. 2014. Biohydrogenation of fatty acids is dependent on plant species and feeding regimen of dairy cows. J. Agric. Food Chem. 62:3570-3576. https://doi.org/10 $.1021 / \mathrm{jf} 405552 \mathrm{~m}$.

Pijlman, J., S. Koopmans, G. de Haan, F. Lenssinck, K. van Houwelingen, J. G. C. Deru, and J. W. Erisman. 2018. Effect of feeding the grass fibrous fraction obtained from biorefinery on $\mathrm{N}$ and $\mathrm{P}$ utilisation of dairy cows. Page 431-433 in Proc. 20th N Workshop and Side Event, Rennes, France. INRA, Rennes, France.

Pirie, N. W. 1978. Leaf Protein and Its By-Products in Human and Animal Nutrition. 2nd ed. Cambridge Univ. Press, Cambridge, UK.
Randby, Å. T., M. R. Weisbjerg, P. Nørgaard, and B. Heringstad. 2012. Early lactation feed intake and milk yield responses of dairy cows offered grass silages harvested at early maturity stages. J. Dairy Sci. 95:304-317. https://doi.org/10.3168/jds.2011-4454.

Santamaría-Fernández, M., M. Ambye-Jensen, V. K. Damborg, and M. Lübeck. 2018. Demonstration scale protein recovery by lactic acid fermentation from grass clover-A single case production of protein concentrate and press cake silage for animal feeding trials. Biofuels Bioprod. Biorefin. 13:502-513.

Savonen, O., M. Franco, T. Stefanski, P. Mäntysaari, K. Kuoppala, and M. Rinne. 2018. Grass silage for biorefinery-Dairy cow responses to diets based on solid fraction of grass silage. Pages 55-60 in Proc. Nordic Feed Sci. Conf. Swedish Univ. Agric. Sci., Uppsala, Sweden.

Simopoulos, A. P. 2002. The importance of the ratio of omega-6/ omega-3 essential fatty acids. Biomed. Pharmacother. 56:365-379. https://doi.org/10.1016/S0753-3322(02)00253-6.

Sjaunja, L. O., L. Baevre, L. Junkkarinen, J. Pedersen, and J. Setälä. 1991. A Nordic proposal for an energy corrected milk (ECM) formula. Performance recordings of animals - State of the art 1990, Paris, France. EAAP Publ. 50:156-157.

Solati, Z., U. Jørgensen, J. Eriksen, and K. Søegaard. 2018. Estimation of extractable protein in botanical fractions of legume and grass species. Grass Forage Sci. 73:572-581. https://doi.org/10.1111/gfs .12325 .

Stødkilde, L., V. K. Damborg, H. Jørgensen, H. N. Lærke, and S. K. Jensen. 2018. White clover fractions as protein source for monogastrics: Dry matter digestibility and protein digestibility-corrected amino acid scores. J. Sci. Food Agric. 98:2557-2563. https://doi .org/10.1002/jsfa. 8744

Stødkilde, L., V. K. Damborg, H. Jørgensen, H. N. Lærke, and S. K. Jensen. 2019. Digestibility of fractionated green biomass as protein source for monogastric animals. Animal 1-9. https://doi.org/10 $.1017 / \mathrm{s} 1751731119000156$.

Tilley, J. M. A., and R. A. Terry. 1963. A two-stage technique for the in vitro digestion of forage crops. Grass Forage Sci. 18:104-111. https://doi.org/10.1111/j.1365-2494.1963.tb00335.x.

Volden, H. 2011. NorFor-The Nordic Feed Evaluation System. Wageningen Acad. Publ., Wageningen, the Netherlands.

Weisbjerg, M. R., and T. Hvelplund. 1993. Bestemmelse af nettoenergiindhold (FEK) i råvarer og kraftfoderblandninger. Statens Husdyrsbrugsfors $\emptyset$ g. Forskningsrapport nr. 3. Tjele, Denmark.

Weisbjerg, M. R., T. Hvelplund, and K. Søegaard. 2002. Prediction of true digestibility and faecal endogenous losses in sheep of protein and total cell content from the proportion of the nutrient in feed dry matter. Pages 143-151 in Proc. Tanzania Society of Animal Production (TSAP) Conf., Morogoro, Tanzania. 